\title{
Deficiency of $\mathbf{N}$-Acetyltransferase Increases the Interactions of Isoniazid with Endobiotics in mouse Liver
}

\author{
Pengcheng Wang ${ }^{1}$, Amina I. Shehu ${ }^{1}$, Jie Lu ${ }^{1}$, Rujuta H. Joshi ${ }^{1}$, Raman Venkataramanan ${ }^{1}$, \\ Kim S. Sugamori ${ }^{2}$, Denis M. Grant ${ }^{2}$, Xiao-bo Zhong ${ }^{3}$, and Xiaochao Ma $^{1}$ \\ ${ }^{1}$ Center for Pharmacogenetics, Department of Pharmaceutical Sciences, School of Pharmacy, \\ University of Pittsburgh, Pittsburgh, PA 15261, USA \\ ${ }^{2}$ Department of Pharmacology and Toxicology, Faculty of Medicine, University of Toronto, Toronto, \\ ON, M5S 1A8, Canada \\ ${ }^{3}$ Department of Pharmaceutical Sciences, School of Pharmacy, University of Connecticut, Storrs, \\ CT 06269, USA
}

\section{Abstract}

Acetylation is the major metabolic pathway of isoniazid (INH) mediated by $N$-acetyltransferases (NATs). Previous reports suggest that slow acetylators have higher risks of INH hepatotoxicity than rapid acetylators, but the detailed mechanisms remain elusive. The current study used Nat1/2(-/-) mice to mimic NAT slow metabolizers and to investigate INH metabolism in the liver. We found that INH acetylation is abolished in the liver of Nat1/2(-/-) mice, suggesting that INH acetylation is fully dependent on NAT1/2. In addition to the acetylation pathway, INH can be hydrolyzed to form hydrazine (Hz) and isonicotinic acid (INA). We found that INA level was not altered in the liver of Nat1/2(-/-) mice, indicating that deficiency of NAT1/2 has no effect on INH hydrolysis. Because INH acetylation was abolished and INH hydrolysis was not altered in Nat1/2(-/-) mice, we expected an extremely high level of INH in the liver. However, we only observed a modest accumulation of INH in the liver of Nat1/2(-/-) mice, suggesting that there are alternative pathways in INH metabolism in NAT1/2 deficient condition. Our further studies revealed that the conjugated metabolites of INH with endobiotics, including fatty acids and vitamin B6, were significantly increased in the liver of Nat1/2(-/-) mice. In summary, this study illustrated that deficiency of NAT1/2 decreases INH acetylation, but increases the interactions of INH with endobiotics in the liver. These findings can be used to guide future studies on the mechanisms of INH hepatotoxicity in NAT slow metabolizers.

Correspondence: Xiaochao Ma, Ph.D., Center for Pharmacogenetics, Department of Pharmaceutical Sciences, School of Pharmacy, University of Pittsburgh, Pittsburgh, PA 15261. Tel. (412) 648-9448; mxiaocha@ pitt.edu.

Author contributions

PW, AIS, JL, and XM performed the experiments. PW, JL, RHJ, and XM conducted data analysis. KSS, DMG, RV, XZ, and XM contributed to the new reagents, analytic tools, and animal models. XM and PW conceived the project and wrote the manuscript.

Conflict of interest

The authors declare that there are no conflicts of interest.

Publisher's Disclaimer: This is a PDF file of an unedited manuscript that has been accepted for publication. As a service to our customers we are providing this early version of the manuscript. The manuscript will undergo copyediting, typesetting, and review of the resulting proof before it is published in its final citable form. Please note that during the production process errors may be discovered which could affect the content, and all legal disclaimers that apply to the journal pertain. 


\section{Graphical abstract}

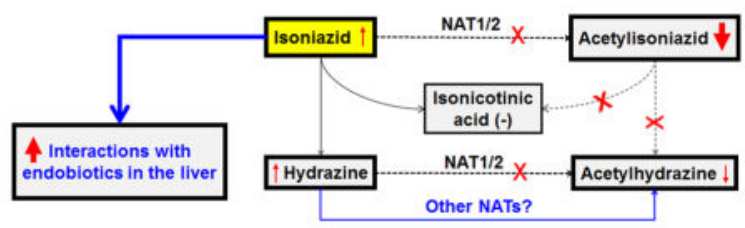

\section{Keywords}

Isoniazid; $N$-acetyltransferase; slow metabolizers; drug metabolism

\section{Introduction}

Isoniazid (INH) is highly effective for tuberculosis therapy, but it frequently causes liver injury [1]. Although the detailed mechanisms of INH hepatotoxicity remain unknown [2-4], INH metabolism has been thought to be associated with INH hepatotoxicity [5-7].

Acetylation is the predominant pathway in INH metabolism [8, 9]. INH acetylation produces acetylisoniazid (AcINH) that can be further hydrolyzed to generate isonicotinic acid (INA) and acetylhydrazine (AcHz) (Fig. 1). Bioactivation of $\mathrm{AcHz}$ has been considered as a cause of INH-induced liver injury [5-7]. INH can also be hydrolyzed to produce INA and hydrazine (Hz) (Fig. 1) $[9,10]$. Hz inhibits mitochondrial complex II and potentially causes mitochondrial injury [11]. In addition, INH itself has been found to undergo bioactivation and possibly lead to immune-mediated liver injury [12, 13]. Furthermore, INH can disturb endobiotic homeostasis in the liver, which may also contribute to INH hepatotoxicity [1417].

$\mathrm{N}$-acetyltransferase (NAT) is the key enzyme in INH metabolism, and it also contributes to $\mathrm{Hz}$ metabolism (Fig. 1) [8-10]. Genetic status of NAT2, and hence the rate of INH acetylation, is associated with INH hepatotoxicity [5, 18-20]. It has been predicted that rapid acetylators should have a higher risk of liver injury than slow acetylators because of $\mathrm{AcHz}$ production $[5,20]$. However, most clinical studies found have that the incidence of INH hepatotoxicity is higher in slow acetylators than rapid acetylators [19, 21-24]. The goal of the current study is to determine the effect of NAT deficiency on INH metabolism in the liver. Our findings will provide the biochemical basis of INH hepatotoxicity in NAT slow metabolizers.

\section{Materials and methods}

\subsection{Chemicals and reagents}

INH, Hz, AcHz, INA, 4-aminobenzoic acid, sulfamethazine, pyridoxal (PL), pyridoxal 5phosphate (PLP), and 4-nitrophenol were purchased from Sigma-Aldrich (St. Louis, MO). AcINH was purchased from Toronto Research Chemicals (Toronto, ON, Canada). All solvents for metabolite analysis were of the highest grade commercially available. 


\subsection{Animals and treatments}

Nat1/2(-/-) mice [25] and wild-type (WT) mice are on the C57BL/6 background. All mice were maintained under a standard $12 \mathrm{~h}$ dark/light cycle with water and chow provided ad libitum. These mice (6-8 weeks old, male, $\mathrm{n}=3-4$ in each group) were orally treated with vehicle or INH. The dose of INH was $50 \mathrm{mg} / \mathrm{kg}$, which was calculated based on the difference in body surface area between humans and mice [26]. After $0.25,0.5,1,2$, 4, or 8 $\mathrm{h}$ of INH treatment, the mice were sacrificed. Liver tissues were harvested and flash-frozen in liquid nitrogen, then stored at $-80{ }^{\circ} \mathrm{C}$ until further analysis. The procedures were in accordance with study protocols approved by the Institutional Animal Care and Use Committee of the University of Pittsburgh.

\subsection{Sample preparation}

Liver samples were homogenized in ice-cold water (100 mg of liver in $500 \mu \mathrm{l}$ of water). To $100 \mu \mathrm{l}$ of each homogenate, $200 \mu \mathrm{l}$ of acetonitrile:methanol (1:1, v/v) was added and followed by vortex ( $30 \mathrm{~s}$ ) and centrifugation $(15,000 \mathrm{~g}$ for $10 \mathrm{~min})$. The supernatant was transferred to a new Eppendorf vial for a second centrifugation (15,000 $\mathrm{g}$ for $10 \mathrm{~min})$. Afterward, $1.0 \mu$ supernatant was injected to ultra-performance liquid chromatography coupled with time-of-flight mass spectrometry (UPLC-TOFMS) (Waters, Milford, MA) for metabolites analysis.

\subsection{Determination of NAT1 and NAT2 activities in Nat1/2(-/-) mice}

Liver cytosols were used for analyzing NAT1 and NAT2 activities. Sulfamethazine and 4aminobenzoic acid were used as probes of NAT1 and NAT2, respectively [27]. In brief, the reaction system included liver cytosol ( $2 \mathrm{mg}$ of protein $/ \mathrm{ml}$ ), $30 \mu \mathrm{M}$ sulfamethazine or 4aminobenzoic acid, $0.5 \mathrm{mM}$ acetyl-coenzyme A, $1 \mathrm{mM}$ EDTA, and $1 \mathrm{mM}$ dithioreitol in 100 $\mu \mathrm{l}$ of $1 \times$ phosphate-buffered saline (PBS, $\mathrm{pH}$ 7.4). The incubations were conducted at $37^{\circ} \mathrm{C}$ for $30 \mathrm{~min}$ (NAT1 assay) or $10 \mathrm{~min}$ (NAT2 assay). The reaction mixtures were terminated by adding $100 \mu \mathrm{l}$ of ice-cold acetonitrile. The samples were vortexed for $30 \mathrm{~s}$ and then centrifuged at 15,000 $\mathrm{g}$ for $10 \mathrm{~min}$. One $\mu \mathrm{l}$ supernatant was injected into UPLC-TOFMS for metabolite analysis.

\subsection{Acetylation of $\mathrm{Hz}$ in liver cytosols of $\mathrm{Nat1/2(-/-)} \mathrm{mice}$}

The reactions were performed with $\mathrm{Hz}(0.5 \mathrm{mM})$, acetyl-CoA $(0.5 \mathrm{mM}), 1 \mathrm{mM}$ EDTA, and 1 $\mathrm{mM}$ dithioreitol, and liver cytosol $(1 \mathrm{mg}$ protein/ml) in PBS. The reaction mixtures were incubated for $30 \mathrm{~min}$ at $37^{\circ} \mathrm{C}$, and then terminated by adding $100 \mu \mathrm{l}$ ice-cold acetonitrile. After vortex and centrifugation, the supernatant fractions were used to measure the acetylated product of $\mathrm{Hz}$ by UPLC-TOFMS.

\subsection{CYP2E1 activity and expression in Nat1/2(-/-) mice}

In addition to NAT, CYP2E1 is considered as an INH metabolizing enzyme [28, 29]. We therefore analyzed CYP2E1 expression and activity in the liver of Nat1/2(-/-) mice. Liver microsomes were used for analysis of CYP2E1 expression and activity. 4-nitrophenol was used as a probe for CYP2E1 activity assay [30]. CYP2E1 expression was analyzed by 
Western-blot $(n=3)$ [31]. The primary antibody against CYP2E1 was purchased from EMD Millipore (Billerica, MA; cat\# AB1252).

\subsection{Metabolite analysis by UPLC-TOFMS}

INH and its metabolites were analyzed by UPLC-TOFMS using previously described methods with a low limit of quantitation at $1 \mathrm{ng} / \mathrm{ml}$ (except AcINH at $8 \mathrm{ng} / \mathrm{ml}$ ) [17, 32, 33]. Briefly, metabolite analysis was performed on an Acquity UPLC BEH C18 column $(2.1 \times$ $100 \mathrm{~mm}, 1.7 \mu \mathrm{m}$; Waters, Milford, MA). The flow rate of the mobile phase was $0.5 \mathrm{ml} / \mathrm{min}$ using a gradient ranging from $2 \%$ to $98 \%$ acetonitrile/water containing $0.1 \%$ formic acid. The column temperature was maintained at $50{ }^{\circ} \mathrm{C}$. TOFMS was operated in positive mode with electrospray ionization. The source and desolvation temperatures were set at $150{ }^{\circ} \mathrm{C}$ and $500{ }^{\circ} \mathrm{C}$, respectively. Nitrogen was applied as cone and desolvation gas, and the gas flow rates were set as $50 \mathrm{l} / \mathrm{h}$ and $800 \mathrm{l} / \mathrm{h}$, respectively. Argon was applied as the collision gas. Capillary and cone voltages were set at $0.8 \mathrm{kV}$ and $40 \mathrm{~V}$. TOFMS was calibrated with sodium formate and monitored by the intermittent injection of lockspray leucine encephalin. MS data were acquired in centroid format over a range of 50-1,000 Da. Tandem mass spectrometry fragmentation was conducted with collision energy ramp ranging from 15 to $45 \mathrm{eV}$.

\subsection{Synthesis of INH-PLP adduct}

We proposed the formation of INH-PLP adduct in mouse liver. Thus, we synthesized this

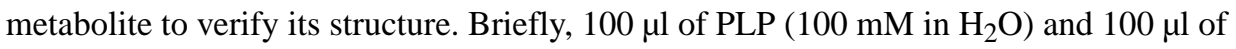
INH $\left(100 \mathrm{mM}\right.$ in $\left.\mathrm{H}_{2} \mathrm{O}\right)$ were added to an Eppendorf tube. The mixture was incubated at $37^{\circ} \mathrm{C}$ for $10 \mathrm{~min}$. The obtained product was analysed by UPLC-TOFMS.

\subsection{Data analysis and statistics}

Area under the concentration-time curve from 0 to $8 \mathrm{~h}\left(\mathrm{AUC}_{0-8 \mathrm{~h}}\right)$ of INH and its metabolites, as well as INH-endobiotics conjugates, in the liver was calculated by noncompartmental analysis (Phoenix WinNonlin, version 6.4; Pharsight, Mountain View, CA). All quantification data are expressed as mean or mean \pm SD. Statistical analysis was performed with two-tailed Student's $t$ tests using Graphpad Prism 6 (Graphpad Software, San Diego, CA). A $P$ value less than 0.05 was considered to be statistically significant.

\section{Results}

\subsection{Hepatic activities of NAT1, NAT2, and CYP2E1 in Nat1/2(-/-) mice}

As expected, both NAT1 and NAT2 activities were significantly suppressed in the liver of Nat1/2(-/-) mice (Fig. 2A and 2B). CYP2E1 is also thought to be involved in INH metabolism and hepatotoxicity [28, 29]. Therefore, we examined CYP2E1 expression and activity in the liver of Nat1/2(-/-) mice. We did not observe any differences in CYP2E1 expression and activity between the livers of WT and Nat1/2(-/-) mice (Fig. 2C and 2D). 


\subsection{INH acetylation in the liver of Nat1/2(-/-) mice}

INH acetylation produces AcINH. Following INH administration, AcINH rapidly reached maximum concentration in the liver of WT mice (Fig. 3A). In contrast, AcINH was not detected in the liver of Nat1/2(-/-) mice (Fig. 3A and 3B). These data suggest that INH acetylation is fully dependent on NAT1/2.

\subsection{INH hydrolysis in the liver of Nat1/2(-/-) mice}

In addition to the acetylation pathway, INH can be hydrolyzed by amidases to form $\mathrm{Hz}$ and INA [2, 34, 35]. However, no significant difference was found in the hepatic level of INA between Nat1/2(-/-) and WT mice following INH administration (Fig. 4A and 4B). In addition, the hepatic level of $\mathrm{Hz}$ only increased slightly in Nat1/2(-/-) mice when compared to WT mice (Fig. 4C and 4D). Furthermore, we compared amidase activity between WT and Nat1/2(-/-) mice by incubating INH in liver microsomes, but no significant difference was observed in $\mathrm{Hz}$ formation (data not shown). These data indicate that NAT1/2 deficiency has no effect on amidase activity and INH hydrolysis.

\section{4. $\mathrm{Hz}$ acetylation in the liver of Nat1/2(-/-) mice}

$\mathrm{Hz}$ can be further acetylated to form $\mathrm{AcHz}$ and NAT2 is responsible for this metabolic

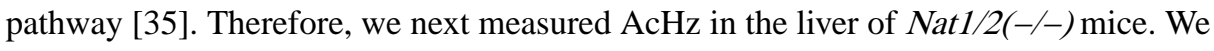
found that $\mathrm{AcHz}$ concentration only decreased 35\% in the liver of Nat1/2(-/-) mice when compared to WT mice (Fig. 5A and 5B). Because INH acetylation was fully abolished in the liver of Nat1/2(-/-) mice (Fig. 3), AcHz cannot be produced from AcINH hydrolysis, but only from $\mathrm{Hz}$ acetylation. These data suggest that the mechanism of $\mathrm{Hz}$ acetylation is different from that of INH acetylation, and it is not exclusively dependent on NAT1/2. Consistent with the in vivo data, there was no significant difference in $\mathrm{Hz}$ acetylation in the liver cytosols of WT and Nat1/2(-/-) mice (Fig. 5C), indicating that other isoforms of NAT are involved in $\mathrm{Hz}$ acetylation.

\subsection{INH levels in the liver of Nat1/2(-/-) mice}

INH acetylation and hydrolysis are the major pathways in INH metabolism [2, 34]. Because INH acetylation was fully abolished and there was no change in INH hydrolysis (Fig. 3 and 4), we expected a tremendous accumulation of INH in the liver of Nat1/2(-/-) mice.

However, INH levels only increased $86 \%$ in the liver of Nat1/2(-/-) mice when compared to WT mice (Fig. 6). These data suggest there are alternative pathways in INH metabolism in addition to INH acetylation and hydrolysis.

\subsection{INH-fatty acid interactions in the liver of Nat1/2(-/-) mice}

INH can react with fatty acids to form INH-fatty acid amides [17]. Here, we found that the formation of INH-fatty acid amides $1(\mathrm{~m} / \mathrm{z} 402.3126)$ and $2(\mathrm{~m} / \mathrm{z} 400.2956)$ was significantly increased in the liver of $N a t 1 / 2(-/-)$ mice when compared to WT mice. The hepatic level of INH-fatty acid amide 1 reached maximum concentration at $1 \mathrm{~h}$ after INH administration in Nat1/2(-/-) mice (Fig. 7A). Compared to WT mice, the $\mathrm{AUC}_{0-8 \mathrm{~h}}$ of INHfatty acid amide 1 increased $68 \%$ in the liver of $N a t 1 / 2(-/-)$ mice (Fig. 7B). The hepatic level of INH-fatty acid amide 2 reached maximum concentration at $0.25 \mathrm{~h}$ after INH 
administration in Nat1/2(-/-) mice (Fig. 7C). The $\mathrm{AUC}_{0-8 \mathrm{~h}}$ of INH-fatty acid amide 2 was $84 \%$ higher in the liver of Nat1/2(-/-) mice than WT mice (Fig. 7D).

\subsection{INH-vitamin B6 (PL and PLP) interactions in the liver of Nat1/2(-/-) mice}

PL and PLP are two major forms of vitamin B6. The hydrazine group in INH has been found to react with the aldehyde group in PL to form INH-PL adduct [17, 36]. We found that the formation of INH-PL adduct was significantly increased in the liver of Nat1/2(-/-) mice when compared to WT mice (Fig. $8 \mathrm{~A}$ ), as the $\mathrm{AUC}_{0-8 \mathrm{~h}}$ of hepatic INH-PL was two-fold higher in Nat1/2(-/-) mice than WT mice (Fig. 8B). In addition to INH-PL adduct, we found that INH can also react with PLP to form INH-PLP adduct. INH-PLP was eluted at $2.53 \mathrm{~min}$ (Fig. 8C). The structure of INH-PLP was further elucidated by MS/MS fragment analysis and confirmed by comparing the retention time and MS/MS fragments with the synthetic standard (Fig. 8D). The formation of INH-PLP adduct was also increased in the liver of Nat1/2(-/-) mice when compared to WT mice, especially at the $1 \mathrm{~h}$ and $2 \mathrm{~h}$ time points after INH treatment (Fig. 8E). The $\mathrm{AUC}_{0-8 \mathrm{~h}}$ of hepatic INH-PLP increased $48 \%$ in Nat1/2(-/-) mice when compared to WT mice (Fig. 8F).

\section{Discussion}

The current study focused on the role of NAT1/2 in INH metabolism and disposition in mouse liver. Acetylation and hydrolysis are two known metabolic pathways of INH [2, 34, 35]. We found that deficiency of NAT1/2 totally abolished INH acetylation in the liver. Interestingly, suppression of INH acetylation does not promote INH hydrolysis, but increases the interactions of INH with endobiotics in the liver (Fig. 9).

Our results support that NAT1/2 are critical in INH acetylation [2, 34, 35]. When NAT1 and 2 are deficient, INH acetylation is $100 \%$ suppressed in the liver. We expected that suppression of INH acetylation would promote INH hydrolysis. However, there was no change in INA, a metabolite of INH formed through hydrolysis, suggesting that blockage of the INH acetylation pathway has no effect on the INH hydrolysis pathway. $\mathrm{Hz}$ is also a metabolite of INH generated from hydrolysis. We found a $28 \%$ increase of $\mathrm{Hz}$ in the liver of Nat1/2(-/-) mice when compared to WT, which we believe is caused by the partial blockage of $\mathrm{Hz}$ acetylation, but not by the hydrolysis pathway (Fig. 9).

$\mathrm{Hz}$ can be acetylated to form AcHz by NAT in the liver [2, 34, 35]. In addition, AcHz can be generated through the hydrolysis of AcINH. Since the formation of AcINH was fully blocked in the liver of Nat1/2(-/-) mice, AcHz cannot be produced through AcINH hydrolysis. Therefore, AcHz can only be generated from $\mathrm{Hz}$ acetylation in the liver of Nat1/2(-/-) mice. We found that the hepatic levels of AcHz only decreased 35\% in Nat1/2(-/-) mice when compared to WT mice, suggesting that other NATs besides NAT1 and NAT2 are involved in $\mathrm{Hz}$ acetylation. These data suggest that the mechanism of $\mathrm{Hz}$ acetylation is different from INH acetylation.

It has been proposed that deficiency of NAT2 increases the risk of INH hepatotoxicity through the possible involvement of $\mathrm{AcHz}$ and $\mathrm{Hz}[19,35]$. AcHz is thought to undergo bioactivation and then lead to INH hepatotoxicity [5-7]. In addition, $\mathrm{Hz}$ was found to inhibit 
mitochondrial complex II and potentially cause mitochondrial injury [11]. By using Nat1/2(-/-) mice, we revealed that deficiency of NAT1/2 has no significant effect on $\mathrm{AcHz}$ or $\mathrm{Hz}$ levels in the liver, indicating that $\mathrm{AcHz}$ and $\mathrm{Hz}$ may not be critical for INH hepatotoxicity in NAT slow metabolizers.

As for INH itself, we expected a dramatic accumulation of INH in the liver of Nat1/2(-/-) mice because INH acetylation was $100 \%$ abolished and there was no increase in INH hydrolysis. However, we only observed an $86 \%$ increase of INH in the liver of Nat1/2(-/-) mice when compared to WT mice, suggesting that INH undergoes alternative pathways of metabolism beyond acetylation and hydrolysis. Previous studies have shown that INH can interact with endobiotics in the liver to form adducts [15-17]. In the current study, we profiled the interactions of INH with fatty acids and vitamin B6 (PL and PLP) in the liver of Nat1/2(-/-) mice. We found that deficiency of NAT1/2 significantly increases the formation of INH-fatty acid amides, INH-PL, and INH-PLP adducts in the liver (Fig. 9).

INH-fatty acid amides are produced through a replacement reaction, in which INH attacks fatty acyl-CoAs to form amides [17]. Fatty acyl-CoAs are intermediates in fatty acid $\beta$ oxidation [37]. The formation of INH-fatty acid amides indicates that INH can disturb fatty acid $\beta$-oxidation, which can therefore contribute to INH-induced microvesicular steatosis and INH hepatotoxicity $[17,38,39]$. In the current study, we observed higher levels of INHfatty acid amides in the liver of Nat1/2(-/-) mice than WT mice, suggesting that deficiency of NAT1/2 promotes INH-mediated disruption of fatty acid metabolism in the liver and potentiates INH-induced fatty liver.

Vitamin B6 has several forms including PL and PLP. Previous studies have shown that INH can react with PL to form INH-PL adduct $[17,36]$. In addition to the INH-PL adduct, the current study illustrated the formation of INH-PLP adduct, indicating the interactions of INH with PLP. PLP is the active form of vitamin B6 and is the co-factor of various hepatic enzymes that are involved in the metabolic pathways of amino acids, glucose, lipids, etc. $[40,41]$. Deficiency of vitamin B6 can disrupt cellular functions and lead to cytotoxicity [42]. INH can cause PLP deficiency and result in toxicity in the clinic, and supplementation of PL can attenuate the adverse effects of INH [36, 43]. The current study observed higher levels of INH-PL and INH-PLP in the liver of Nat1/2(-/-) mice than WT mice, suggesting that deficiency of NAT1/2 increases INH-vitamin B6 interactions, which can potentiate vitamin B6 deficiency and increase the risk of liver dysfunction.

In summary, the current study used Nat1/2(-/-) mice to investigate INH metabolism in the liver. We confirmed that INH acetylation is dependent on NAT1/2. In addition, we found that: (i) deficiency of NAT1/2 has no effect on INH hydrolysis; (ii) deficiency of NAT1/2 does not dramatically change the levels of $\mathrm{AcHz}$ or $\mathrm{Hz}$ in the liver; and (iii) deficiency of NAT1/2 increases the interactions of INH with endobiotics in the liver (Fig. 9). Our data also suggest that other NATs besides NAT1/2 are involved in $\mathrm{Hz}$ acetylation. These findings provide novel insights into INH metabolism in the liver under the NAT deficient condition, which can be used to guide future studies on the mechanisms of INH hepatotoxicity in NAT slow metabolizers. 


\section{Acknowledgments}

This work was supported in part by the National Institute of Diabetes and Digestive and Kidney Diseases (DK090305), the National Institute of Allergy And Infectious Diseases (R01AI131983), and the National Institute of General Medical Sciences (GM118367).

\section{References}

1. C.f.d. control. Severe isoniazid-associated liver injuries among persons being treated for latent tuberculosis infection - United States, 2004-2008. MMWR Morb Mortal Wkly Rep. 2010; 59(8): 224-9. [PubMed: 20203555]

2. Boelsterli UA, Lee KK. Mechanisms of isoniazid-induced idiosyncratic liver injury: emerging role of mitochondrial stress. J Gastroenterol Hepatol. 2014; 29(4):678-87. [PubMed: 24783247]

3. Metushi IG, Cai P, Zhu X, Nakagawa T, Uetrecht JP. A fresh look at the mechanism of isoniazidinduced hepatotoxicity. Clin Pharmacol Ther. 2011; 89(6):911-4. [PubMed: 21412230]

4. Tostmann A, Boeree MJ, Aarnoutse RE, de Lange WC, van der Ven AJ, Dekhuijzen R. Antituberculosis drug-induced hepatotoxicity: concise up-to-date review. J Gastroenterol Hepatol. 2008; 23(2):192-202. [PubMed: 17995946]

5. Mitchell JR, Zimmerman HJ, Ishak KG, Thorgeirsson UP, Timbrell JA, Snodgrass WR, Nelson SD. Isoniazid liver injury: clinical spectrum, pathology, and probable pathogenesis. Ann Intern Med. 1976; 84(2):181-92. [PubMed: 766682]

6. Nelson SD, Mitchell JR, Timbrell JA, Snodgrass WR, Corcoran GB 3rd. Isoniazid and iproniazid: activation of metabolites to toxic intermediates in man and rat. Science. 1976; 193(4256):901-3. [PubMed: 7838]

7. Sarich TC, Adams SP, Petricca G, Wright JM. Inhibition of isoniazid-induced hepatotoxicity in rabbits by pretreatment with an amidase inhibitor. J Pharmacol Exp Ther. 1999; 289(2):695-702. [PubMed: 10215642]

8. Evans DA, Manley KA, Mc KV. Genetic control of isoniazid metabolism in man. Br Med J. 1960; 2(5197):485-91. [PubMed: 13820968]

9. Ellard GA, Gammon PT. Pharmacokinetics of isoniazid metabolism in man. J Pharmacokinet Biopharm. 1976; 4(2):83-113. [PubMed: 950592]

10. Peretti E, Karlaganis G, Lauterburg BH. Increased urinary excretion of toxic hydrazino metabolites of isoniazid by slow acetylators. Effect of a slow-release preparation of isoniazid. Eur J Clin Pharmacol. 1987; 33(3):283-6. [PubMed: 3691615]

11. Lee KK, Fujimoto K, Zhang C, Schwall CT, Alder NN, Pinkert CA, Krueger W, Rasmussen T, Boelsterli UA. Isoniazid-induced cell death is precipitated by underlying mitochondrial complex I dysfunction in mouse hepatocytes. Free Radic Biol Med. 2013; 65:584-94. [PubMed: 23911619]

12. Metushi IG, Nakagawa T, Uetrecht J. Direct oxidation and covalent binding of isoniazid to rodent liver and human hepatic microsomes: humans are more like mice than rats. Chem Res Toxicol. 2012; 25(11):2567-76. [PubMed: 23016703]

13. Metushi IG, Sanders C, Lee WM, Uetrecht J. Detection of anti-isoniazid and anti-cytochrome P450 antibodies in patients with isoniazid-induced liver failure. Hepatology. 2014; 59(3):1084-93. [PubMed: 23775837]

14. Li F, Lu J, Cheng J, Wang L, Matsubara T, Csanaky IL, Klaassen CD, Gonzalez FJ, Ma X. Human PXR modulates hepatotoxicity associated with rifampicin and isoniazid co-therapy. Nat Med. 2013; 19(4):418-20. [PubMed: 23475203]

15. Sachar M, Li F, Liu K, Wang P, Lu J, Ma X. Chronic Treatment with Isoniazid Causes Protoporphyrin IX Accumulation in Mouse Liver. Chem Res Toxicol. 2016; 29(8):1293-7. [PubMed: 27438535]

16. Cheng J, Krausz KW, Li F, Ma X, Gonzalez FJ. CYP2E1-dependent elevation of serum cholesterol, triglycerides, and hepatic bile acids by isoniazid. Toxicol Appl Pharmacol. 2013; 266(2):245-53. [PubMed: 23142471] 
17. Li F, Wang P, Liu K, Tarrago MG, Lu J, Chini EN, Ma X. A High Dose of Isoniazid Disturbs Endobiotic Homeostasis in Mouse Liver. Drug Metab Dispos. 2016; 44(11):1742-1751. [PubMed: 27531952]

18. Ohno M, Yamaguchi I, Yamamoto I, Fukuda T, Yokota S, Maekura R, Ito M, Yamamoto Y, Ogura T, Maeda K, Komuta K, Igarashi T, Azuma J. Slow N-acetyltransferase 2 genotype affects the incidence of isoniazid and rifampicin-induced hepatotoxicity. Int J Tuberc Lung Dis. 2000; 4(3): 256-61. [PubMed: 10751073]

19. Huang YS, Chern HD, Su WJ, Wu JC, Lai SL, Yang SY, Chang FY, Lee SD. Polymorphism of the $\mathrm{N}$-acetyltransferase 2 gene as a susceptibility risk factor for antituberculosis drug-induced hepatitis. Hepatology. 2002; 35(4):883-9. [PubMed: 11915035]

20. Mitchell JR, Thorgeirsson UP, Black M, Timbrell JA, Snodgrass WR, Potter WZ, Jollow HR, Keiser HR. Increased incidence of isoniazid hepatitis in rapid acetylators: possible relation to hydranize metabolites. Clin Pharmacol Ther. 1975; 18(1):70-9. [PubMed: 1149365]

21. Ng CS, Hasnat A, Al Maruf A, Ahmed MU, Pirmohamed M, Day CP, Aithal GP, Daly AK. Nacetyltransferase 2 (NAT2) genotype as a risk factor for development of drug-induced liver injury relating to antituberculosis drug treatment in a mixed-ethnicity patient group. Eur J Clin Pharmacol. 2014; 70(9):1079-86. [PubMed: 24888881]

22. Gupta VH, Amarapurkar DN, Singh M, Sasi P, Joshi JM, Baijal R, Ramegowda PH, Amarapurkar $\mathrm{AD}$, Joshi K, Wangikar PP. Association of N-acetyltransferase 2 and cytochrome P450 2E1 gene polymorphisms with antituberculosis drug-induced hepatotoxicity in Western India. J Gastroenterol Hepatol. 2013; 28(8):1368-74. [PubMed: 23875638]

23. Chamorro JG, Castagnino JP, Musella RM, Nogueras M, Aranda FM, Frias A, Visca M, Aidar O, Peres S, de Larranaga GF. Sex, ethnicity, and slow acetylator profile are the major causes of hepatotoxicity induced by antituberculosis drugs. J Gastroenterol Hepatol. 2013; 28(2):323-8. [PubMed: 23190413]

24. Bose PD, Sarma MP, Medhi S, Das BC, Husain SA, Kar P. Role of polymorphic N-acetyl transferase 2 and cytochrome P4502E1 gene in antituberculosis treatment-induced hepatitis. J Gastroenterol Hepatol. 2011; 26(2):312-8. [PubMed: 21261721]

25. Sugamori KS, Wong S, Gaedigk A, Yu V, Abramovici H, Rozmahel R, Grant DM. Generation and functional characterization of arylamine $\mathrm{N}$-acetyltransferase Nat1/Nat2 double-knockout mice. Mol Pharmacol. 2003; 64(1):170-9. [PubMed: 12815173]

26. Bertrand J, Verstuyft C, Chou M, Borand L, Chea P, Nay KH, Blanc FX, Mentre F, Taburet AM. Dependence of efavirenz- and rifampicin-isoniazid-based antituberculosis treatment drug-drug interaction on CYP2B6 and NAT2 genetic polymorphisms: ANRS 12154 study in Cambodia. J Infect Dis. 2014; 209(3):399-408. [PubMed: 23990572]

27. Hein DW, Bendaly J, Neale JR, Doll MA. Systemic functional expression of N-acetyltransferase polymorphism in the F344 Nat2 congenic rat. Drug Metab Dispos. 2008; 36(12):2452-9. [PubMed: 18799801]

28. Huang YS, Chern HD, Su WJ, Wu JC, Chang SC, Chiang CH, Chang FY, Lee SD. Cytochrome P450 2E1 genotype and the susceptibility to antituberculosis drug-induced hepatitis. Hepatology. 2003; 37(4):924-30. [PubMed: 12668988]

29. Yue J, Peng RX, Yang J, Kong R, Liu J. CYP2E1 mediated isoniazid-induced hepatotoxicity in rats. Acta Pharmacol Sin. 2004; 25(5):699-704. [PubMed: 15132840]

30. Cheung C, Yu AM, Ward JM, Krausz KW, Akiyama TE, Feigenbaum L, Gonzalez FJ. The cyp2e1humanized transgenic mouse: role of cyp2e1 in acetaminophen hepatotoxicity. Drug Metab Dispos. 2005; 33(3):449-57. [PubMed: 15576447]

31. Liu K, Li F, Lu J, Gao Z, Klaassen CD, Ma X. Role of CYP3A in isoniazid metabolism in vivo. Drug Metab Pharmacokinet. 2014; 29(2):219-22. [PubMed: 24172716]

32. Li F, Miao Y, Zhang L, Neuenswander SA, Douglas JT, Ma X. Metabolomic analysis reveals novel isoniazid metabolites and hydrazones in human urine. Drug Metab Pharmacokinet. 2011; 26(6): 569-76. [PubMed: 21844656]

33. Tan B, Lu Z, Dong S, Zhao G, Kuo MS. Derivatization of the tricarboxylic acid intermediates with O-benzylhydroxylamine for liquid chromatography-tandem mass spectrometry detection. Anal Biochem. 2014; 465:134-47. [PubMed: 25102203] 
34. Preziosi P. Isoniazid: metabolic aspects and toxicological correlates. Curr Drug Metab. 2007; 8(8): 839-51. [PubMed: 18220565]

35. Wang P, Pradhan K, Zhong XB, Ma X. Isoniazid metabolism and hepatotoxicity. Acta pharmaceutica Sinica B. 2016; 6(5):384-392. [PubMed: 27709007]

36. Mandel W. Pyridoxine and the isoniazid-induced neuropathy. Dis Chest. 1959; 36:293-6. [PubMed: 14420556]

37. Rinaldo P, Matern D, Bennett MJ. Fatty acid oxidation disorders. Annu Rev Physiol. 2002; 64(1): 477-502. [PubMed: 11826276]

38. Church RJ, Wu H, Mosedale M, Sumner SJ, Pathmasiri W, Kurtz CL, Pletcher MT, Eaddy JS, Pandher K, Singer M, Batheja A, Watkins PB, Adkins K, Harrill AH. A systems biology approach utilizing a mouse diversity panel identifies genetic differences influencing isoniazid-induced microvesicular steatosis. Toxicol Sci. 2014; 140(2):481-92. [PubMed: 24848797]

39. Mach J, Huizer-Pajkos A, Mitchell SJ, McKenzie C, Phillips L, Kane A, Jones B, de Cabo R, Cogger V, Le Couteur DG, Hilmer SN. The effect of ageing on isoniazid pharmacokinetics and hepatotoxicity in Fischer 344 rats. Fundam Clin Pharmacol. 2016; 30(1):23-34. [PubMed: 26454000]

40. Schneider G, Kack H, Lindqvist Y. The manifold of vitamin B6 dependent enzymes. Structure. 2000; 8(1):R1-6. [PubMed: 10673430]

41. Binkley F, Christensen GM, Jensen WN. Pyridoxine and the transfer of sulfur. The Journal of biological chemistry. 1952; 194(1):109-13. [PubMed: 14927597]

42. Depeint F, Bruce WR, Shangari N, Mehta R, O'Brien PJ. Mitochondrial function and toxicity: role of B vitamins on the one-carbon transfer pathways. Chem Biol Interact. 2006; 163(1-2):113-32. [PubMed: 16814759]

43. Wason S, Lacouture PG, Lovejoy FH Jr. Single high-dose pyridoxine treatment for isoniazid overdose. JAMA. 1981; 246(10):1102-4. [PubMed: 7265398] 

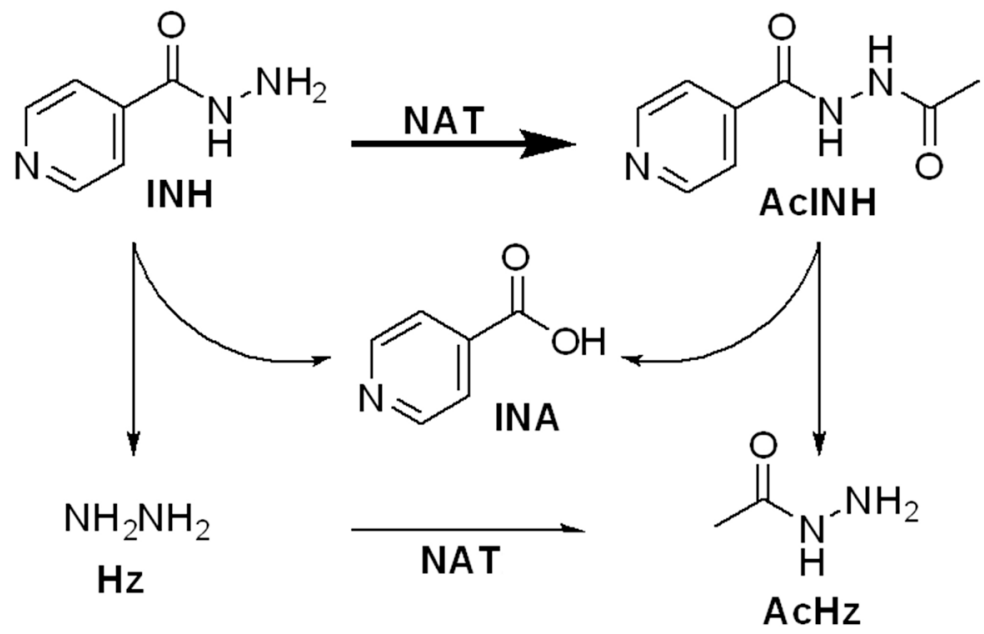

Fig. 1. The major metabolic pathways of isoniazid (INH)

AcINH, acetylisoniazid; Hz, hydrazine; INA, isonicotinic acid; AcHz, acetylhydrazine; NAT, $N$-acetyltransferase. 

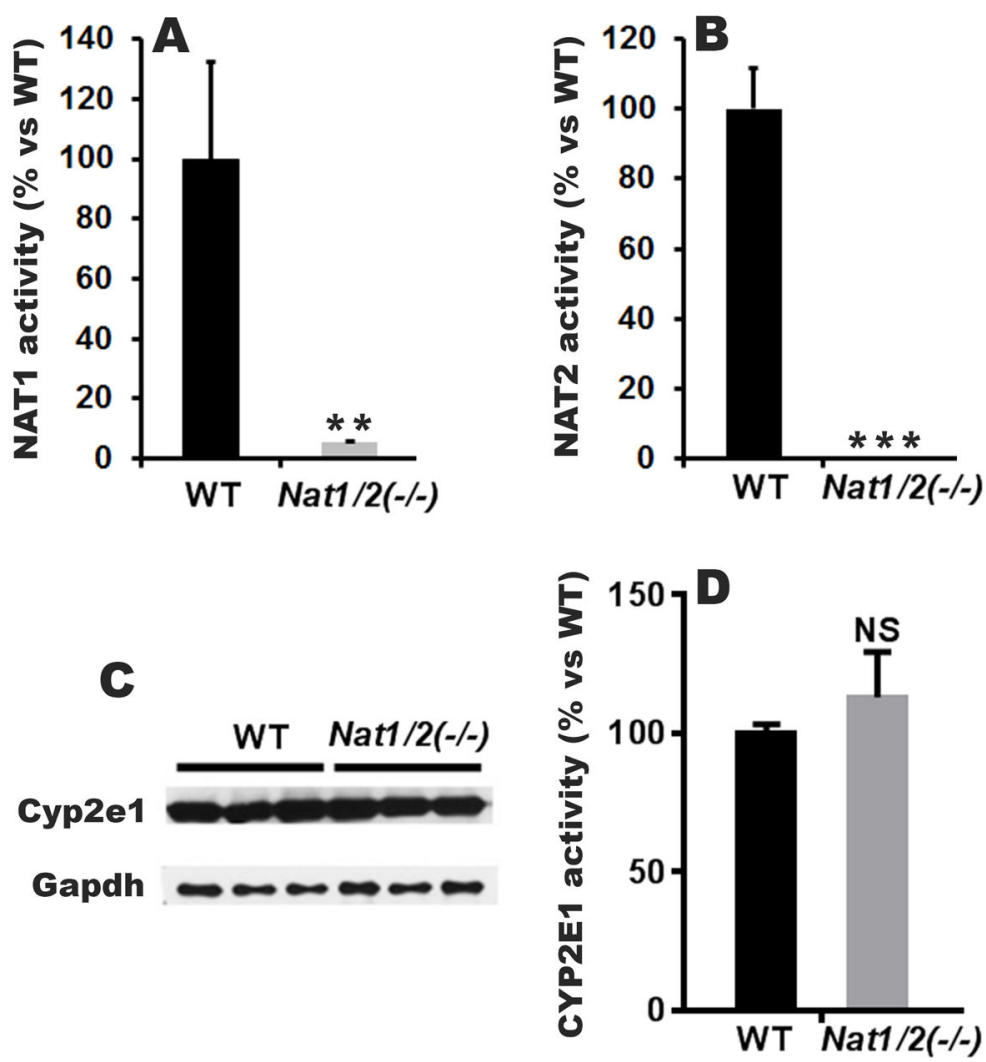

Fig. 2. Expression and activity of INH metabolizing enzymes in the liver of Nat1/2(-/-) mice $(\mathbf{A}, \mathbf{B})$ NAT1 and NAT2 activities in the liver cytosols of WT and Nat1/2(-/-) mice. Sulfamethazine and 4-aminobenzoic acid were used as probes for the assays of NAT1 (A) and NAT2 (B), respectively. (C) Western-blot analysis of CYP2E1 in the liver microsomes of WT and Nat1/2(-/-) mice. Gapdh was used as the loading control. (D) Activity of CYP2E1 in the liver microsomes of WT and Nat1/2(-/-) mice. 4-nitrophenol was used as a probe. All data were expressed as mean $\pm \mathrm{SD}(\mathrm{n}=3-4)$ and the data in WT mice were set as $100 \%$. ** $P<0.01, * * * P<0.001$ vs WT mice. NS, not significant $(P>0.05)$. 

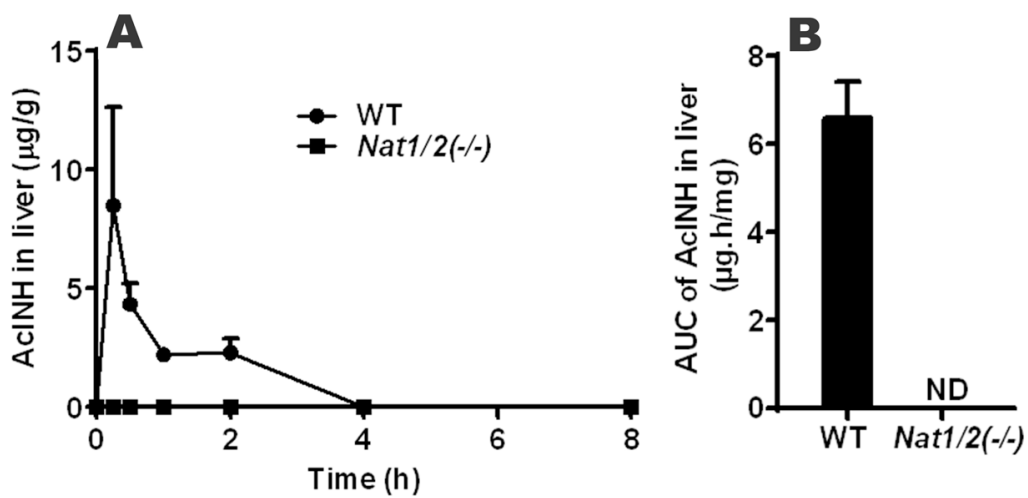

Fig. 3. INH acetylation in the liver of WT and Nat1/2(-/-) mice WT and Nat1/2(-/-) mice $(\mathrm{n}=4)$ were treated with $50 \mathrm{mg} / \mathrm{kg}$ of INH (po). Liver samples were collected at $0.25,0.5,1,2,4$, or $8 \mathrm{~h}$ after INH treatment. (A) AcINH in the liver of WT and Nat1/2(-/-) mice after INH treatment. (B) $\mathrm{AUC}_{0-8 \mathrm{~h}}$ of $\mathrm{AcINH}$ in the liver of WT and Nat1/2(-/-) mice. The data are expressed as mean \pm SD. ND, not detected. 

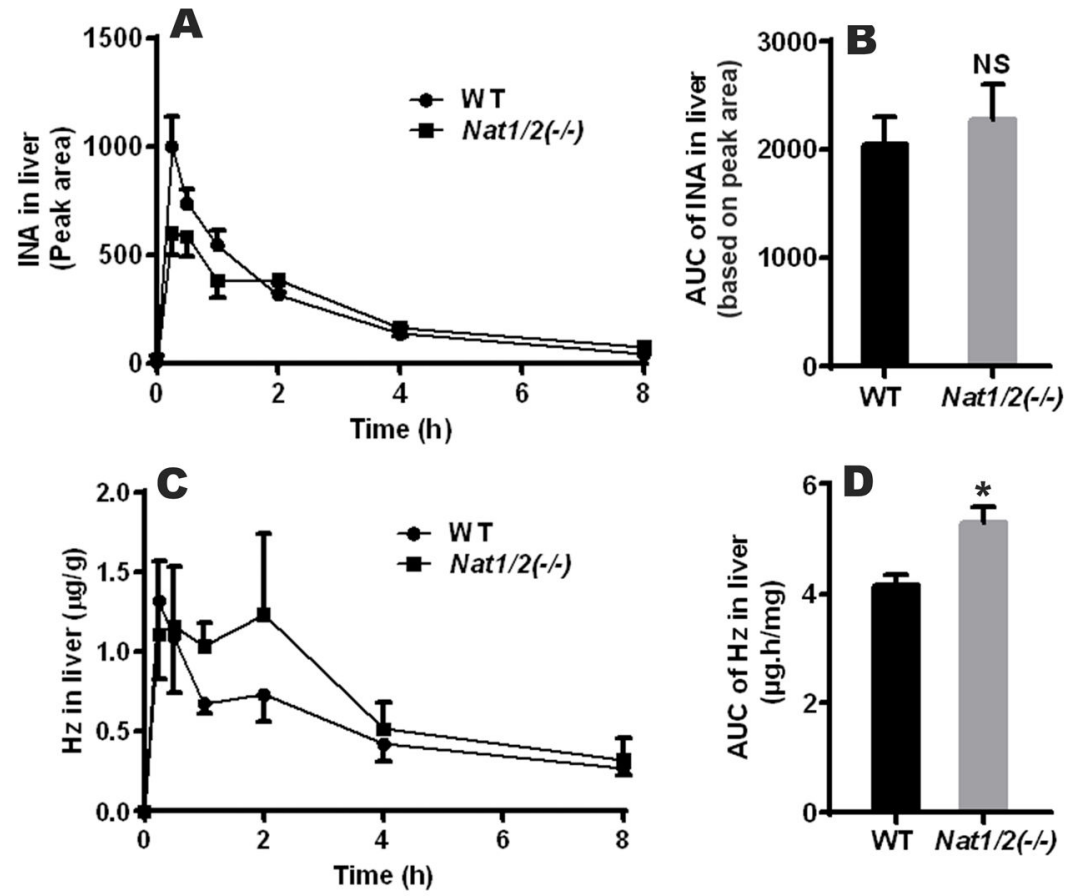

Fig. 4. INH hydrolysis in the liver of WT and Nat1/2(-/-) mice WT and Nat1/2(-/-) mice ( $(\mathrm{n}=4)$ were treated with $50 \mathrm{mg} / \mathrm{kg}$ of INH (po). Liver samples were collected at $0.25,0.5,1,2,4$, or $8 \mathrm{~h}$ after INH treatment. (A) INA in the liver of WT and Nat1/2(-/-) mice after INH treatment. (B) $\mathrm{AUC}_{0-8 \mathrm{~h}}$ of INA in the liver of WT and Nat1/2(-/-) mice. (C) $\mathrm{Hz}$ in the liver of WT and Nat1/2(-/-) mice after INH treatment. (D) $\mathrm{AUC}_{0-8 \mathrm{~h}}$ of $\mathrm{Hz}$ in the liver of WT and Nat1/2(-/-) mice. The data were expressed as mean \pm SD. $* P<0.05$ vs WT mice. NS, not significant $(P>0.05)$. 

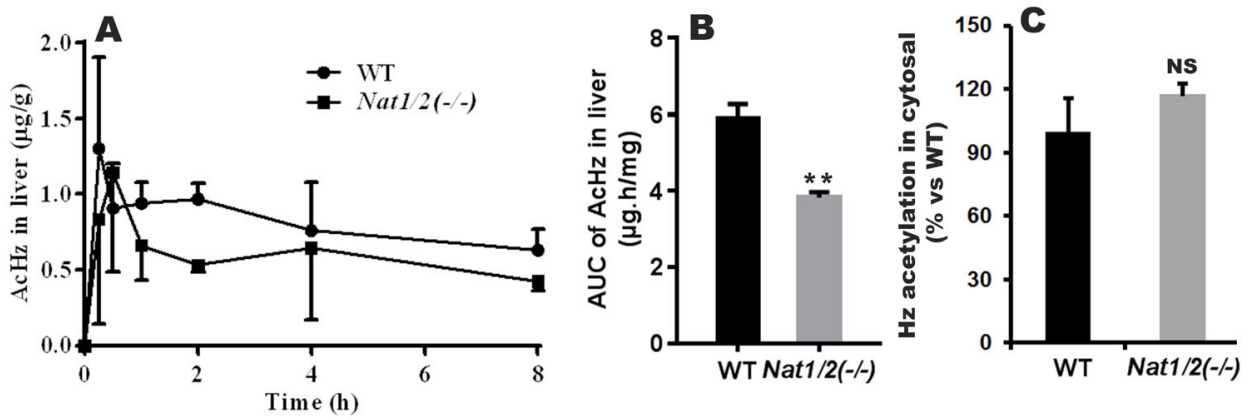

Fig. 5. Hz acetylation in the liver of WT and Nat1/2(-/-) mice WT and Nat1/2(-/-) mice $(\mathrm{n}=4)$ were treated with $50 \mathrm{mg} / \mathrm{kg}$ of INH (po). Liver samples were collected at $0.25,0.5,1,2,4$, or $8 \mathrm{~h}$ after INH treatment. (A) AcHz in the liver of WT and Nat1/2(-/-) mice after INH treatment. (B) $\mathrm{AUC}_{0-8 \mathrm{~h}}$ of $\mathrm{AcHz}$ in the liver of WT and Nat1/2(-/-) mice. (C) Hz acetylation in the liver cytosols of WT and Nat1/2(-/-) mice (n = 4). The data are expressed as mean $\pm \mathrm{SD}$. $* * P<0.01$ vs WT mice. NS, not significant $(P>$ $0.05)$. 

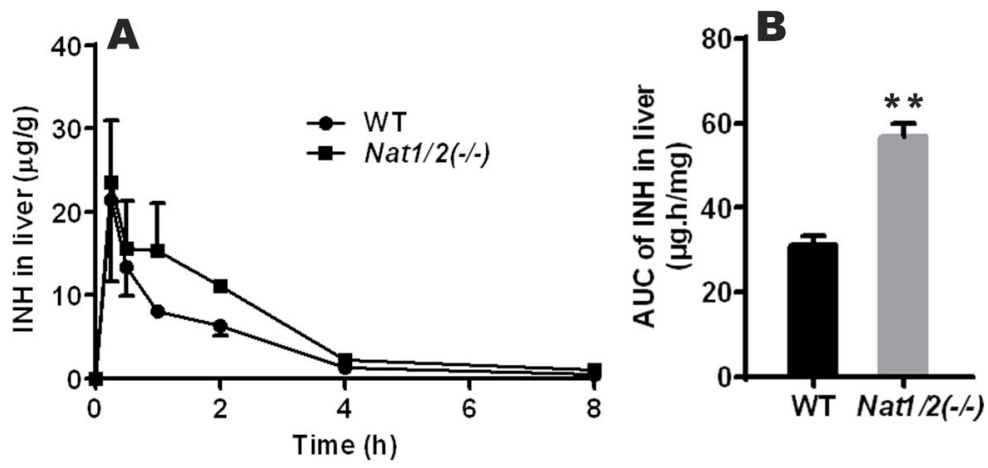

Fig. 6. INH levels in the liver of WT and Nat1/2(-/-) mice WT and Nat1/2(-/-) mice ( $(\mathrm{n}=4)$ were treated with $50 \mathrm{mg} / \mathrm{kg}$ of INH (po). Liver samples were collected at $0.25,0.5,1,2,4$, or $8 \mathrm{~h}$ after INH treatment. (A) INH in the liver of WT and Nat1/2(-/-) mice after INH treatment. (B) $\mathrm{AUC}_{0-8 \mathrm{~h}}$ of INH in the liver of WT and Nat1/2(-/-) mice. The data were expressed as mean $\pm \mathrm{SD}$. $* * P<0.01$ vs WT mice. 

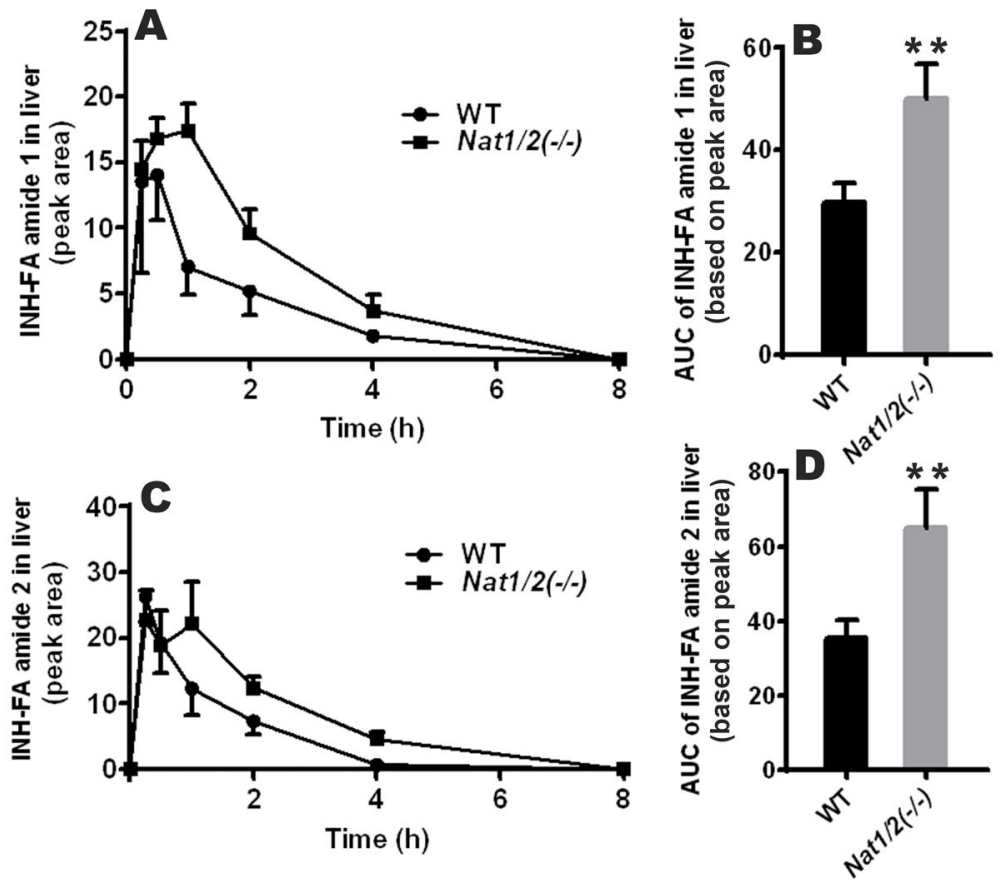

Fig. 7. Interactions of INH with fatty acids in the liver of WT and Nat1/2(-/-) mice WT and Nat1/2(-/-) mice ( $\mathrm{n}=4$ ) were treated with $50 \mathrm{mg} / \mathrm{kg}$ of INH (po). Liver samples were collected at $0.25,0.5,1,2,4$, or $8 \mathrm{~h}$ after INH treatment. (A, C) INH-fatty acid (FA) amide 1 (A) and $2(\mathbf{C})$ in the liver of WT and Nat1/2(-/-) mice after INH treatment. (B, D) $\mathrm{AUC}_{0-8 \mathrm{~h}}$ of INH-FA amide 1 (B) and 2 (D) in the liver of WT and Nat1/2(-/-) mice. The data were expressed as mean \pm SD. $* * P<0.01$ vs WT mice. 

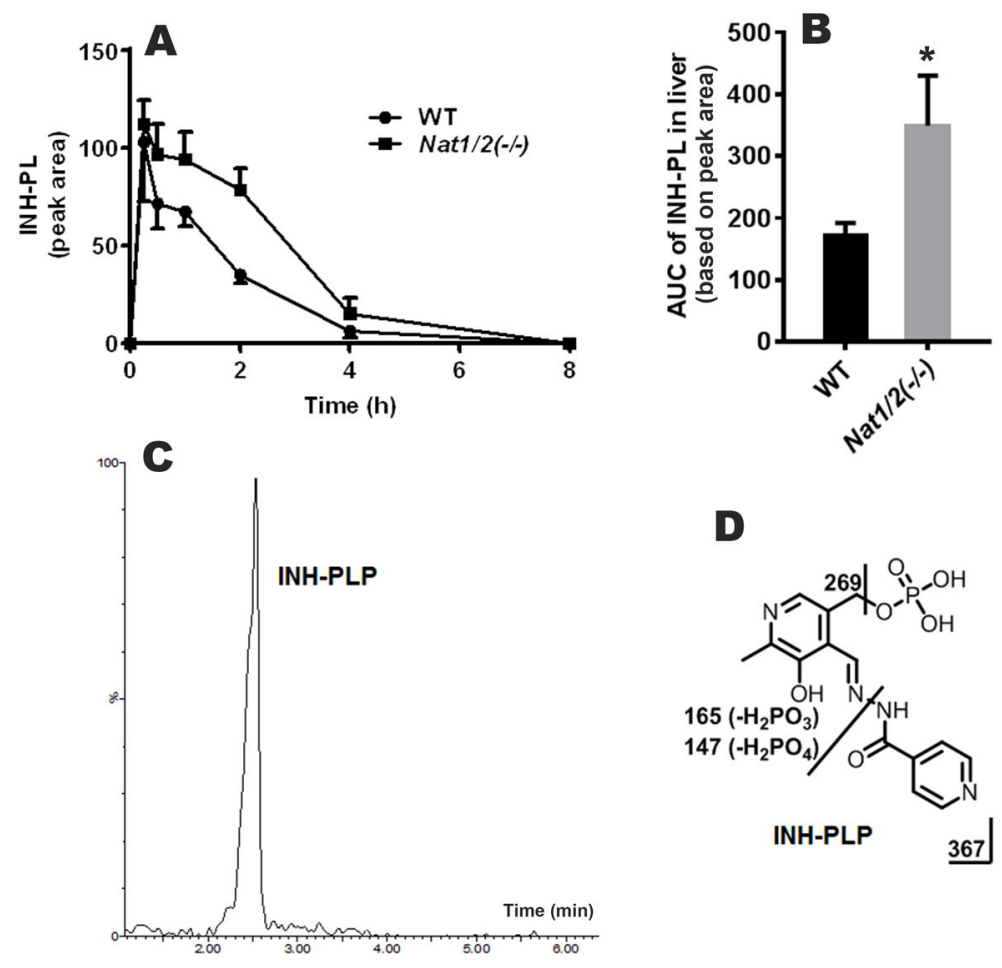

D
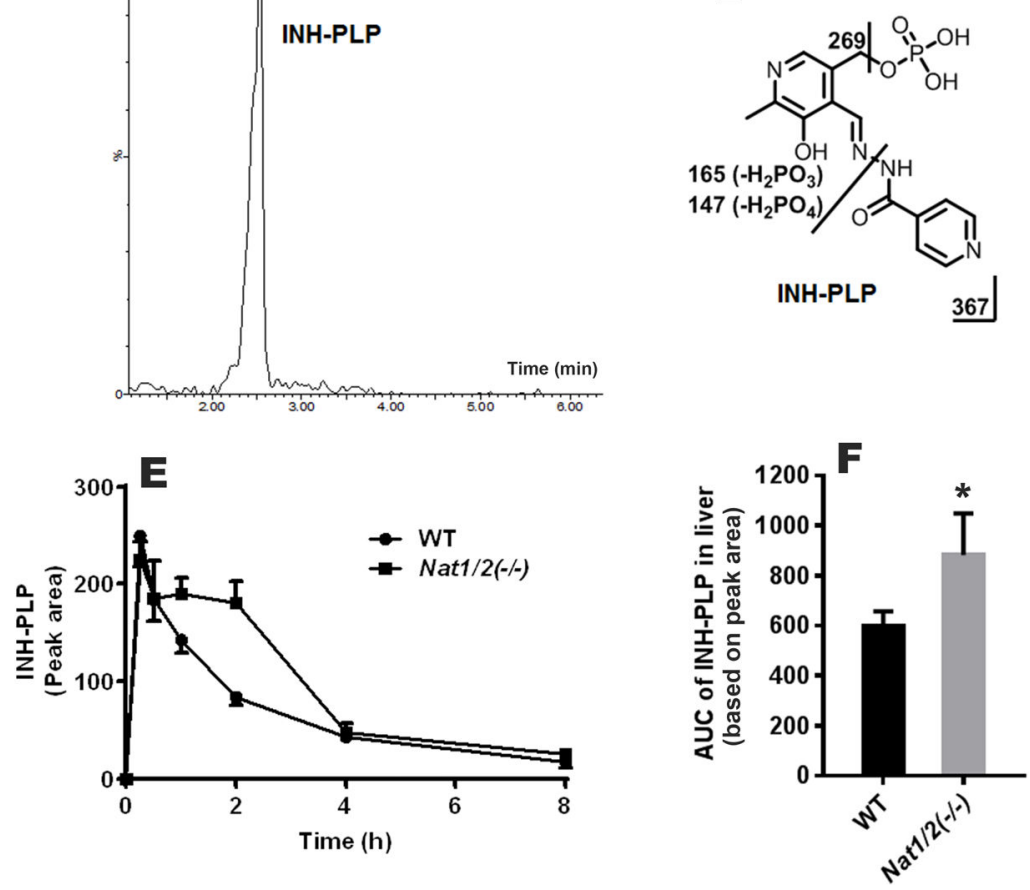

Fig. 8. Interactions of INH with vitamin B6 (PL and PLP) in the liver of WT and Nat1/2(-/-) mice

WT and Nat1/2(-/-) mice ( $\mathrm{n}=4$ ) were treated with $50 \mathrm{mg} / \mathrm{kg}$ of INH (po). Liver samples were collected at $0.25,0.5,1,2,4$, or $8 \mathrm{~h}$ after INH treatment. (A) INH-PL adduct in the liver of WT and Nat1/2(-/-) mice after INH treatment. (B) $\mathrm{AUC}_{0-8 \mathrm{~h}}$ of INH-PL adduct in the liver of WT and Nat1/2(-/-) mice. (C) The extract chromatogram of INH-PLP. (D) Structural illustration of INH-PLP by MS/MS fragmental analysis. (E) INH-PLP adduct in the liver of WT and Nat1/2(-/-) mice after INH treatment. (F) $\mathrm{AUC}_{0-8 \mathrm{~h}}$ of INH-PLP in the liver of WT and Nat1/2(-/-) mice. The data were expressed as mean \pm SD. $* P<0.05$ vs WT mice. 


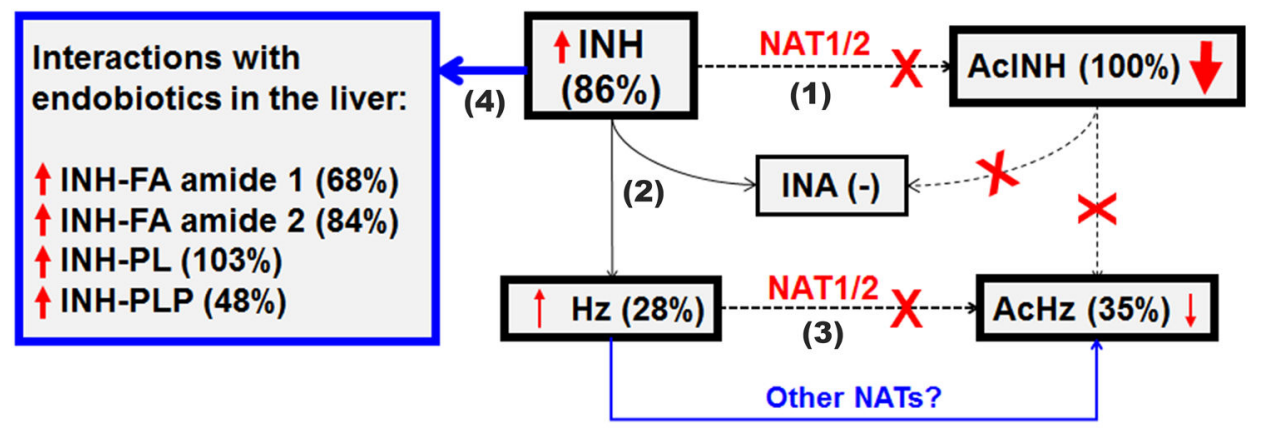

Fig. 9. Deficiency of $N$-acetyltransferase (NAT) 1 and 2 potentiates the interactions of INH with endobiotics in the liver

Compared to WT mice, INH metabolism in the liver of Nat1/2(-/-) mice was altered as follows: (1) INH acetylation is fully abolished; (2) there is no change in INH hydrolysis; (3) $\mathrm{Hz}$ acetylation is partially suppressed; and (4) the interactions of INH with endobiotics in the liver are significantly increased. FA, fatty acid; PL, pyridoxal; PLP, pyridoxal 5phosphate. (X), blockage; $(\uparrow)$, increase; $(\downarrow)$, decrease; $(-)$, no change; $(\%)$, percentage of alteration in $\mathrm{Nat} 1 / 2(-/-)$ mice vs WT mice. 